\title{
Quality Characteristics of Dried Persimmon Prepared By Different Pretreatments*
}

\section{Mun-Gyeong Cho ${ }^{1}$, Ji-Hyeong Cho ${ }^{1}$, Eun-Mi Park ${ }^{1}$, Sanjeev Kumar Dhungana ${ }^{2}$, II-Doo Kim ${ }^{3}$}

\author{
${ }^{1}$ Agricultural Research \& Extension Services, Sangju Persimmon Research Institute, \\ Gyeongsangbukdo, Sangju 37268, Korea \\ ${ }^{2}$ School of Applied Biosciences, Kyungpook National University, Daegu 41566, Korea \\ ${ }^{3}$ International Institute of Research \& Development, Kyungpook National University, Daegu 41566, Korea \\ *M-G Cho and J-H Cho equally contributed to this work.
}

\begin{abstract}
Persimmon is one of the widely cultivated fruits in Korea, China, and Japan. The fruits of persimmon contain various phytochemicals which have health promoting effects. Drying is one of the most oldest and famous fruit processing techniques. The objective of this study was to investigate the effect of different pretreatments on moisture content, soluble solid content, and firmness of dried persimmon fruit. The moisture content of HCT (dried persimmon prepared by soaking in $50 \mathrm{ppm}$ sodium hypochlorite for $1 \mathrm{~min}$ at $20^{\circ} \mathrm{C}$ ) and ACT (dried persimmon prepared by soaking into $1 \% \mathrm{~N}$-acetylcysteine for $1 \mathrm{~min}$ at $20^{\circ} \mathrm{C}$ ) followed by STT (dried persimmon prepared by soaking the fruits into $5 \%$ salt solution containing $1 \%$ citric acid for $1 \mathrm{~min}$ at $65^{\circ} \mathrm{C}$ ) showed the significantly low moisture content on 6 days of drying. The soluble solid content of HCT and MST (dried persimmon prepared by soaking into $0.5 \%$ sodium metabisulfite for $1 \mathrm{~min}$ at $20^{\circ} \mathrm{C}$ ) was significantly low at 6 DAD compared to the other treatments. Similarly, the firmness of ACT showed a high value on day 6 . The firmness of HCT was significantly low as in the control followed by MST on day 6. The results indicated that fruit pretreatment by soaking in 50 ppm sodium hypochlorite solution could be a good option to enhance the quality characteristics of dried persimmon fruits.
\end{abstract}

Keywords: Dried Persimmon, Firmness, Moisture Content, Pretreatment, Soluble Solid Content

\section{Introduction}

Persimmon (Diospyros kaki Thunb.) is grown in subtropical and warm temperate climatic regions. The fruits have been established as one of the major fruits in China, Japan, and Korea for a long time. They contain numerous phytochemicals (Lia et al., 2013; Butt et al., 2015), including ascorbic acids, condensed tannins, and carotenoids, which have good antioxidant properties (Rao and Rao, 2007; Shahkoomahally et al., 2015; Fu et al., 2016). They are also a good source of dietary fibers, vitamins, and minerals. The fruits were believed to help cure various health problems, like hypertension, coughs, frostbite, paralysis, burns and bleeding (Veberic et al., 2010) in the ancient medicine. Consumption of persimmon fruit has been found beneficial for the prevention of atherosclerosis (Zhang et al., 2016) as well. They also possess various bio-physiological functions, including hypolipidemic, arteriosclerosis prevention, anticancer and antiviral activities (Kamimoto et al., 2014). The fruits are considered beneficial against some health problems such as coughs, hypertension, dyspnoea, paralysis, burns, and bleeding because the fruit is rich in nutrients such as vitamin $\mathrm{C}$, vitamin $\mathrm{A}$, calcium, iron, and phenolic compounds (Nicoleti et al., 2007). Reports also show that persimmon contains an inhibitory effect on human lymphoid leukemia cells, mutagenicity of Cnitro and C-nitroso compounds (Achiwa et al., 1997) as well as stroke and the extension of the lifespan of hypertensive rats (Uchida et al., 1995; Xie et al., 2015).

A consumption of persimmon fruits throughout the year is important to have its tremendous health benefits, however a regular supply of fresh fruits is difficult because it is grown only in a particular season in specific climatic regions. Some people are also reluctant to have fresh fruits (Byrne, 2002). Such a circumstance favors for production of high quality processed fruits.

Drying is probably the oldest and easiest method of food preservation (Dehydration, 1998). Drying inhibits the microbiological activity and improves the shelf life of foods. Dehydrated fruits and pulps have received high interest in the recent years due to their advantages, such as easy availability, retention of the

This article is published under the terms of the Creative Commons Attribution License 4.0

Author(s) retain the copyright of this article. Publication rights with Alkhaer Publications.

Published at: http://www.ijsciences.com/pub/issue/2018-11/

DOI: 10.18483/ijSci.1846; Online ISSN: 2305-3925; Print ISSN: 2410-4477 
characteristics of natural products, low volume and thus less transportation cost, and safe due to low moisture content for prevention of the growth of harmful microorganisms (Marques et al., 2006). Persimmon fruits can also be preserved by drying and make them available during the off-seasons when fresh fruits could not be harvested. Drying could also be done to reduce the astringency and improve the acceptability of the fruits as astringency and color play important roles in quality characteristics of dried persimmon (Akyıldız et al., 2004).

A number of reports on the methods of drying and its effect on persimmon fruits have been available. However, the effect of various pretreatments on the quality of dries persimmon is not well documented. The study was designed to investigate the quality characteristics of dried persimmon applied with different methods of pretreatments before drying.

\section{Materials and Methods \\ Preparation of dried persimmon samples}

In the present study, persimmon (Diosyris kaki Thunb.) cv. Sangjudoongsi, grown at Sangju Persimmon Research Institute, Sangju-Si Gyeongsang buk-do, South Korea, was selected for the study. The cultivar selected in this study was one of the famous cultivar of that region. The average weight of the persimmon fruits was $180 \mathrm{~g}$ and the yield was $148-185 \mathrm{~kg}$ per tree which was quite acceptable for a commercial production. The fruits were harvested at commercial maturity stage in October of 2017 and were transported to the laboratory within $6 \mathrm{~h}$ of harvest.

Almost equal-sized fruits were selected and washed with tap water and then kept at room temperature for surface drying. The fruits were subjected to ethylene gas treatment for $24 \mathrm{~h}$ in order to remove the astringency and then the fruits were peeled off manually using a peeler. The fruits, after peeling, were cut into four pieces and allowed to different treatments before drying. The samples were named accordingly as control: dried persimmon prepared without any treatment; SFT: dried persimmon prepared by fumigation with sulfur powder for 15 min at container $(1 \mathrm{~m} \times 1 \mathrm{~m} \times 1 \mathrm{~m})$; STT: dried persimmon prepared by soaking the fruits into $5 \%$ salt solution containing $1 \%$ citric acid for $1 \mathrm{~min}$ at $65^{\circ} \mathrm{C}$; RBT: dried persimmon prepared by spraying rice bran extracts (in $98 \%$ ethanol) and $1 \%$ citric acid for $2 \mathrm{~min}$ at $20^{\circ} \mathrm{C}$; HCT: dried persimmon prepared by soaking in $50 \mathrm{ppm}$ sodium hypochlorite for $1 \mathrm{~min}$ at $20^{\circ} \mathrm{C}$; MST: dried persimmon prepared by soaking into $0.5 \%$ sodium metabisulfite for $1 \mathrm{~min}$ at $20^{\circ} \mathrm{C}$; ACT: dried persimmon prepared by soaking into $1 \%$ $\mathrm{N}$-acetylcysteine for $1 \mathrm{~min}$ at $20^{\circ} \mathrm{C}$. The treated fruits were dried at room temperature.

\section{Determination of soluble solid content}

Soluble solid content (SSC) was determined using a refractometer (RX-5000a. Atogo, Tokyo, Japan) and the value was expressed as ${ }^{\circ}$ Brix. All the measurements were made in triplicate and average value were reported.

\section{Determination of moisture content and hardness}

Moisture content was measured following a standard method (AOAC, 1995 method 950.46). The hardness of dried fruits was determined using a rheometer (Compac-100, Sun Scientific Co. Ltd., Tokyo, Japan) under the following operational conditions: test type, mastication; adaptor type, circle; adaptor area, 0.20 $\mathrm{cm}^{2}$; and table speed, $60 \mathrm{~mm} / \mathrm{min}$.

\section{Statistical analysis}

Data were subjected to analysis of variance (ANOVA) using SAS9.4 (SAS Institute Inc., Cary, NC, USA). Differences between treatment means were separated using Tukey test at $\mathrm{p} \leq 0.05$.

\section{Results and Discussion Moisture content}

The moisture content of drying fruits were significantly different from the day 0 (Table 1). RBT showed the significantly low moisture content on day 0 but was increased on 6 days after drying (DAD). HCT $(34.19 \%)$ and ACT $(33.25 \%)$ followed by STT $(37.25 \%)$ showed the significantly low moisture content on 6 DAD. On the other hand, SFT (41.11\%) and RBT $(40.14 \%)$ showed the significantly high moisture content as did the control $(41.25 \%)$ after 6 days of drying.

Similar result of low moisture content with citric acid or $\mathrm{N}$-acetylcysteine treatment was also found in a previous report (Tapia et al., 2007). The lower moisture content with HCT, ACT, and STT might be due to elevated water vapor permeability and water loss effect of hydrophilic compounds like citric acid as well as N-acetylcysteine (Ayrancy and Tunc, 2004). 
Table 1. Changes in moisture content $(\%)$ of dried persimmon prepared by different treatments during drying

\begin{tabular}{lccccccc}
\hline \multirow{2}{*}{ Sample $^{1)}$} & \multicolumn{7}{c}{ Drying (days) } \\
\cline { 2 - 7 } & 0 & 1 & 2 & 3 & 4 & 5 & 6 \\
\hline Control & $82.09 \pm 1.34^{\mathrm{a}}$ & $82.02 \pm 0.81^{\mathrm{a}}$ & $76.12 \pm 0.72^{\mathrm{a}}$ & $74.00 \pm 1.60^{\mathrm{b}}$ & $66.89 \pm 1.20^{\mathrm{cd}}$ & $43.66 \pm 1.31^{\mathrm{bc}}$ & $41.25 \pm 0.33^{\mathrm{a}}$ \\
SFT & $81.88 \pm 0.90^{\mathrm{a}}$ & $80.17 \pm 0.25^{\mathrm{b}}$ & $75.16 \pm 0.86^{\mathrm{b}}$ & $76.27 \pm 0.62^{\mathrm{a}}$ & $67.16 \pm 0.25^{\mathrm{b}}$ & $40.27 \pm 1.00^{\mathrm{d}}$ & $41.11 \pm 0.25^{\mathrm{a}}$ \\
STT & $82.55 \pm 0.52^{\mathrm{a}}$ & $81.44 \pm 0.35^{\mathrm{a}}$ & $73.32 \pm 0.88^{\mathrm{c}}$ & $70.15 \pm 0.32^{\mathrm{d}}$ & $65.25 \pm 0.62^{\mathrm{c}}$ & $45.61 \pm 1.01^{\mathrm{b}}$ & $37.25 \pm 0.36^{\mathrm{c}}$ \\
RBT & $79.71 \pm 1.32^{\mathrm{b}}$ & $78.66 \pm 1.25^{\mathrm{b}}$ & $75.25 \pm 0.86^{\mathrm{b}}$ & $73.00 \pm 0.25^{\mathrm{c}}$ & $64.11 \pm 0.51^{\mathrm{d}}$ & $42.00 \pm 0.92^{\mathrm{c}}$ & $40.14 \pm 0.86^{\mathrm{a}}$ \\
HCT & $83.11 \pm 0.32^{\mathrm{a}}$ & $80.17 \pm 0.25^{\mathrm{b}}$ & $78.11 \pm 0.67^{\mathrm{a}}$ & $74.16 \pm 0.52^{\mathrm{b}}$ & $63.72 \pm 0.77^{\mathrm{d}}$ & $43.16 \pm 0.52^{\mathrm{c}}$ & $34.19 \pm 0.67^{\mathrm{d}}$ \\
MST & $83.61 \pm 0.93^{\mathrm{a}}$ & $80.16 \pm 0.83^{\mathrm{b}}$ & $76.27 \pm 0.25^{\mathrm{ab}}$ & $75.92 \pm 0.63^{\mathrm{a}}$ & $69.52 \pm 0.60^{\mathrm{a}}$ & $48.00 \pm 0.31^{\mathrm{a}}$ & $38.33 \pm 0.68^{\mathrm{b}}$ \\
ACT & $82.77 \pm 1.26^{\mathrm{a}}$ & $79.15 \pm 1.32^{\mathrm{b}}$ & $77.00 \pm 1.12^{\mathrm{a}}$ & $73.53 \pm 0.37^{\mathrm{c}}$ & $64.23 \pm 0.27^{\mathrm{d}}$ & $44.20 \pm 0.27^{\mathrm{b}}$ & $33.25 \pm 0.92^{\mathrm{d}}$
\end{tabular}

${ }^{1)}$ Samples are defined in preparation of dried persimmon samples (Materials and Methods).

${ }^{2)}$ Quoted values are means \pm SD of triplicate measurements. Values followed by different superscripts in the same column are significantly different $(\mathrm{p}<0.05)$.

\section{Soluble solid of dried persimmon}

The SSC of dried persimmon exposed to different pretreatment methods were significantly different 1 DAD (Table 2). However, the variation in SSC was not significant on day 0 . The variation in SSC of different pretreatment was not consistent during the drying period. STT showed lowest value on day 1 but was found with the highest value on day 6. MST which had the highest SSC after ACT on day 2 showed the lowest SSC after HCT on day 6. The SSC of HCT and MST was significantly low at 6 DAD compared to the other treatments.

A lower SSC in fresh-cut melons with sodium hypochlorite treatment was also observed by Dilmaçünal et al. (2014) and Manuwong et al. (2007). The gradual increase in SSC of the samples during drying was perhaps due to dehydration (Apai, 2010; Hai et al., 2014).

Table 2. Changes in Soluble solid $\left({ }^{\circ}\right.$ Brix) of dried persimmon prepared by different treatments during drying

\begin{tabular}{|c|c|c|c|c|c|}
\hline \multirow{2}{*}{ Sample ${ }^{1)}$} & \multicolumn{5}{|c|}{ Drying (days) } \\
\hline & 0 & 2 & 3 & 5 & 6 \\
\hline Control & $17.34 \pm 1.04^{\mathrm{a}} 17.32 \pm 0.91^{\mathrm{bc}}$ & $20.32 \pm 0.27^{b}$ & $32.44 \pm 0.81^{\mathrm{a}} 40.12 \pm 0.16^{\mathrm{b}}$ & $54.00 \pm 1.02^{b c}$ & $54.16 \pm 0.65^{d}$ \\
\hline SFT & $17.84 \pm 0.62^{\mathrm{a}} 18.92 \pm 0.71^{\mathrm{a}}$ & $19.12 \pm 0.36^{\mathrm{bc}}$ & $23.55 \pm 0.25^{\mathrm{c}} 37.72 \pm 0.88^{\mathrm{c}}$ & $56.18 \pm 1.00^{\mathrm{b}}$ & $55.14 \pm 0.75^{b}$ \\
\hline STT & $15.96 \pm 1.76^{\mathrm{a}} 16.31 \pm 0.66^{\mathrm{c}}$ & $19.34 \pm 0.96^{b}$ & $22.44 \pm 1.67^{c} 40.21 \pm 0.92^{b}$ & $60.31 \pm 0.96^{\mathrm{a}}$ & $66.32 \pm 0.62^{\mathrm{a}}$ \\
\hline RBT & $18.22 \pm 1.63^{\mathrm{a}} \quad 18.56 \pm 0.40^{\mathrm{a}}$ & $18.29 \pm 0.81^{\mathrm{c}}$ & $23.18 \pm 1.24^{\mathrm{c}} 43.25 \pm 0.82^{\mathrm{a}}$ & $53.71 \pm 0.88^{c}$ & $55.25 \pm 0.25^{\mathrm{c}}$ \\
\hline $\mathrm{HCT}$ & $16.08 \pm 1.24^{\mathrm{a}} \quad 17.66 \pm 0.21^{\mathrm{b}}$ & $18.17 \pm 1.11^{\mathrm{c}}$ & $22.92 \pm 1.10^{c} 41.33 \pm 0.85^{b}$ & $50.28 \pm 0.62^{\mathrm{e}}$ & $52.38 \pm 0.82^{\mathrm{e}}$ \\
\hline MST & $16.96 \pm 1.14^{\mathrm{a}} 16.98 \pm 0.35^{\mathrm{c}}$ & $22.00 \pm 1.21^{\mathrm{a}}$ & $23.77 \pm 0.92^{\mathrm{c}} 37.32 \pm 1.10^{\mathrm{c}}$ & $52.66 \pm 0.21^{\mathrm{d}}$ & $53.12 \pm 0.76^{\mathrm{e}}$ \\
\hline ACT & $17.10 \pm 1.53^{\mathrm{a}} 17.32 \pm 0.26^{\mathrm{bc}}$ & $24.12 \pm 1.31^{\mathrm{a}}$ & $27.12 \pm 0.77^{\mathrm{b}} 40.12 \pm 1.21^{\mathrm{b}}$ & $56.31 \pm 1.62^{b}$ & $63.00 \pm 0.34^{\mathrm{b}}$ \\
\hline
\end{tabular}

${ }^{1)}$ Samples are defined in preparation of dried persimmon samples (Materials and Methods).

${ }^{2}$ Quoted values are means \pm SD of triplicate measurements. Values followed by different superscripts in the same column are significantly different $(\mathrm{p}<0.05)$.

\section{Firmness of dried persimmon}

The firmness of dried persimmon subjected to various pretreatment methods were significantly different from the day 0 (Table 3). As for the SSC, the variation in firmness of the fruits experienced different pretreatments did not show consistent trend during the drying period. ACT which showed a significantly low firmness on day $0\left(29.64 \mathrm{~kg} / \mathrm{cm}^{2}\right)$ showed a high value on day $6\left(13.27 \mathrm{~kg} / \mathrm{cm}^{2}\right)$. The firmness of HCT $\left(6.18 \mathrm{~kg} / \mathrm{cm}^{2}\right)$ was significantly low as in the control $\left(6.12 \mathrm{~kg} / \mathrm{cm}^{2}\right)$ followed by MST $\left(7.15 \mathrm{~kg} / \mathrm{cm}^{2}\right)$ on day 6 . 
A decrease in firmness of fresh-cut lemon (Dilmaçünal et al., 2014) and tomato (Hong and Gross, 1998) was also observed with sodium hypochlorite treatment as found for HCT in the present study. The effect of potassium metasulfite to reduce the firmness of persimmon fruit, MST was also in agreement with the results found in fresh-cut potato cubes (Rinaldi et al., 2009).

Table 3. Changes in firmness $\left(\mathrm{kg} / \mathrm{cm}^{2}\right)$ of dried persimmon prepared by different treatments during drying

\begin{tabular}{lccccccc}
\hline \multirow{2}{*}{ Sample $^{1)}$} & \multicolumn{7}{c}{ Drying (days) } \\
\cline { 2 - 8 } & 0 & 1 & 2 & 3 & 4 & 5 & 6 \\
\hline Control & $52.26 \pm 1.52^{\mathrm{b}}$ & $76.12 \pm 5.61^{\mathrm{d}}$ & $18.12 \pm 1.92^{\mathrm{a}}$ & $9.21 \pm 1.01^{\mathrm{b}}$ & $8.72 \pm 1.00^{\mathrm{de}}$ & $6.72 \pm 0.16^{\mathrm{e}}$ & $6.12 \pm 0.17^{\mathrm{e}}$ \\
SFT & $76.01 \pm 2.27^{\mathrm{a}}$ & $121.12 \pm 3.27^{\mathrm{a}}$ & $19.31 \pm 2.11^{\mathrm{a}}$ & $11.17 \pm 1.21^{\mathrm{b}}$ & $8.98 \pm 1.02^{\mathrm{e}}$ & $8.88 \pm 0.11^{\mathrm{d}}$ & $8.00 \pm 0.20^{\mathrm{c}}$ \\
STT & $33.24 \pm 4.74^{\mathrm{d}}$ & $68.00 \pm 3.25^{\mathrm{e}}$ & $17.66 \pm 2.31^{\mathrm{a}}$ & $12.31 \pm 2.00^{\mathrm{ab}}$ & $12.20 \pm 0.92^{\mathrm{b}}$ & $11.18 \pm 0.13^{\mathrm{b}}$ & $10.12 \pm 0.35^{\mathrm{b}}$ \\
RBT & $32.24 \pm 4.92^{\mathrm{d}}$ & $104.12 \pm 4.11^{\mathrm{b}}$ & $12.25 \pm 3.52^{\mathrm{b}}$ & $10.92 \pm 1.21^{\mathrm{b}}$ & $10.11 \pm 0.11^{\mathrm{c}}$ & $9.81 \pm 0.25^{\mathrm{c}}$ & $8.00 \pm 0.27^{\mathrm{c}}$ \\
HCT & $48.21 \pm 3.81^{\mathrm{c}}$ & $71.25 \pm 4.10^{\mathrm{de}}$ & $15.92 \pm 2.20^{\mathrm{a}}$ & $11.39 \pm 2.01^{\mathrm{b}}$ & $10.12 \pm 0.12^{\mathrm{c}}$ & $8.32 \pm 0.31^{\mathrm{d}}$ & $6.18 \pm 0.89^{\mathrm{e}}$ \\
MST & $54.46 \pm 3.58^{\mathrm{b}}$ & $86.45 \pm 5.00^{\mathrm{c}}$ & $15.27 \pm 3.00^{\mathrm{a}}$ & $10.27 \pm 1.31^{\mathrm{b}}$ & $9.27 \pm 0.25^{\mathrm{d}}$ & $8.18 \pm 0.51^{\mathrm{d}}$ & $7.15 \pm 0.25^{\mathrm{d}}$ \\
ACT & $29.64 \pm 4.26^{\mathrm{e}}$ & $30.60 \pm 3.26^{\mathrm{f}}$ & $16.11 \pm 3.21^{\mathrm{a}}$ & $15.27 \pm 1.00^{\mathrm{a}}$ & $14.77 \pm 1.02^{\mathrm{a}}$ & $14.00 \pm 1.00^{\mathrm{a}}$ & $13.27 \pm 0.54^{\mathrm{a}}$ \\
\hline
\end{tabular}

${ }^{\mathrm{T}}$ Samples are defined in preparation of dried persimmon samples (Materials and Methods).

${ }^{2)}$ Quoted values are means \pm SD of triplicate measurements. Values followed by different superscripts in the same column are significantly different $(\mathrm{p}<0.05)$.

In conclusion, persimmon fruits were subjected to various pretreatment before drying in order to investigate the effect of different pretreatments on the quality characteristics in terms of moisture content, soluble solid content, and firmness of dried fruits. The results showed that the moisture content of HCT (dried persimmon prepared by soaking in $50 \mathrm{ppm}$ sodium hypochlorite for $1 \mathrm{~min}$ at $20^{\circ} \mathrm{C}$ ) and ACT (dried persimmon prepared by soaking into $1 \% \mathrm{~N}$ acetylcysteine for $1 \mathrm{~min}$ at $20^{\circ} \mathrm{C}$ ) followed by STT (dried persimmon prepared by soaking the fruits into $5 \%$ salt solution containing $1 \%$ citric acid for $1 \mathrm{~min}$ at $65^{\circ} \mathrm{C}$ ) showed the significantly low moisture content on 6 days of drying. The soluble solid content of HCT and MST (dried persimmon prepared by soaking into $0.5 \%$ sodium metabisulfite for $1 \mathrm{~min}$ at $20^{\circ} \mathrm{C}$ ) was significantly low at $6 \mathrm{DAD}$ compared to the other treatments. Similarly, the firmness of ACT showed a high value on day 6 . The firmness of HCT was significantly low as in the control followed by MST on day 6 . The results indicated that the quality characteristics of dried persimmon could be affected by the pretreatment methods.

\section{References}

1. Achiwa $\mathrm{Y}$, Hibasami H, Katsuzaki H, Imai K, Komiya T (1997). Inhibitory effects of persimmon (Diospyros kaki) extract and related polyphenol compounds on growth of human lymphoid leukaemia cells. Bioscience, Biotechnology and Biochemistry. 61: 1099-1101.

2. Akyıldız A, Aksay S, Benli H, Kıroğlu F, Fenercioğlu H (2004). Determination of changes in some characteristics of persimmon during dehydration at different temperatures. Journal of Food Engineering. 65: 95-99.

3. Apai W (2010). Effects of fruit dipping in hydrochloric acid then rinsing in water on fruit decay and browning of longan fruit. Crop Protection. 29: 1184-1189.
4. Ayrancy E, Tunc S (2004). The effect of edible coatings on water and vitamin C loss of apricots (Armeniaca vulgaris Lam.) and green peppers (Capsicum annuиm L.). Food Chemistry. 87: 339-42.

5. Butt MS, Sultan MT, Aziz M, Naz A, Ahmed W, Kumar N, Imran M (2015). Persimmon (Diospyros kaki) fruit: hidden phytochemicals and health claims. EXCLI Journal. 14: 542-561.

6. Byrne D H (2002). Peach breeding trends: a worldwide perspective. Acta Horticulturae. 592: 49-59.

7. Dehydration (1998). In Encyclopaedia Britannica Online [online] Retrieved from https://global.britannica.com/topic/dehydration-foodpreservation [17 November, 2018].

8. Dilmaçünal T, Erbaş D, Koyuncu MA, Onursal CE, Kuleaşan $\mathrm{H}$ (2014). Efficacy of some antimicrobial treatments compared to sodium hypochlorite on physical, physiological and microbial quality of fresh-cut melons (Cucumis melo L. var. Inodorus). LWT-Food Science and Technology. 59: 1146-1151.

9. Fu L, Lu W, Zhou X (2016). Phenolic compounds and in vitro antibacterial and antioxidant activities of three tropic fruits: persimmon, guava, and sweetsop. BioMed Research International. Article ID 4287461.

10. Graham HN (1992). Green tea composition, consumption and polyphenol chemistry. Preventive Medicine. 21: 334

11. Hai LH, Uthaibutra J, Chanbang Y, Joomwong A (2014). Effects of bee-carnauba mixed wax coating on the reduction of respiration rate, weight loss, fruit decay, and the maintenance of visual appearance and quality of Vietnamese longan cv. Long during low temperature storage. International Journal of Agriculture Innovations and Research. 2: 554-560.

12. Hong JH, Gross KC (1998). Surface sterilization of whole tomato fruit with sodium hypochlorite influences subsequent postharvest behavior of fresh-cut slices. Postharvest Biology and Technology. 13: 51-58.

13. Kamimoto M, Nakai Y, Tsuji T, Shimamoto T, Shimamoto T (2014). Antiviral effects of persimmon extract on human norovirus and its surrogate, bacteriophage MS2. Journal of Food Science. 79: 941-946. 
14. Lia C, Zou B, Dong X, Zhang Y, Du J (2013). Current progress on structure analysis and health benefits of persimmon tannin. Acta Horticulturae. 996: 455-466.

15. Manuwong S, Uthairatanakij A, Jitaree P (2007). Effects of hot water and sodium hypochlorite treatments on survival of Salmonella spp. and qualities of fresh-cut pineapple. In International Conference on Quality Management of Fresh Cut Produce, 2007 Aug 6 (pp. 401-408).

16. Marques LG, Silveira AM, Freire JT (2006). Freeze-drying characteristics of tropical fruits. Drying Technology. 24: 457-463.

17. Nicoleti JF, Silveira V, Tlis-Romero J, Telis VRN (2007). Influence of drying conditions on ascorbic acid during convective drying of whole persimmons. Drying Technology. 25: 891-899.

18. Rao AV, Rao LG (2007). Carotenoids and human health. Pharmacological Research. 55: 207-216.

19. Rinaldi R, Cabezas-Serrano AB, Cornacchia R, Amodio ML, Colelli G (2009). Response of Fresh-Cut Potato Cubes of Three Different Varieties to Anti-Browning Treatments. In X International Controlled and Modified Atmosphere Research Conference, 2009 Apr 4 (pp. 319-324).

20. Shahkoomahally S, Ramezanian A, Farahnaky A (2015). Postharvest nitric oxide treatment of persimmon (Diospyros kaki L.) improves fruit quality during storage. Fruits. 70: 6368.

21. Tapia MS, Rojas-Graü MA, Rodríguez FJ, Ramírez J, Carmona A, Martin-Belloso O (2007). Alginate-and gellanbased edible films for probiotic coatings on fresh-cut fruits. Journal of Food Science. 72: E190-196.

22. Uchida S, Ozaki M, Akashi T, Ysmsdhts K, Niwa M, Taniyama K (1995). Effects of (-)-epigallocatechin-3-ogallate (green tea tannin) on the life span of stoke-prone spontaneously hypertensive rates. Clinical and Experimental Pharmacology and Physiology. 1: 302-303.

23. Veberic R, Jurhar J, Mikulic-Petkovsek M, Stampar F, Schmitzer V (2010). Comparative study of primary and secondary metabolites in 11 cultivars of persimmon fruit (Diospyros kaki L.) Food Chemistry. 119: 477-483.

24. Xie C, Xie Z, Xu X, Yang D (2015). Persimmon (Diospyros kaki L.) leaves: A review on traditional uses, phytochemistry and pharmacological properties. Journal of Ethnopharmacology. 163: 229-240.

25. Zhang K, Zhang Y, Zhang M, Gu L, Liu Z, Jia J, Chen X (2016). Effects of phospholipid complexes of total flavonoids from Persimmon (Diospyros kaki L.) leaves on experimental atherosclerosis rats. Journal of Ethnopharmacology. 191: 245-253. 